\title{
INFLUENCE OF DIFFERENT OPTIONS OF INTRA- VARIETAL POLLINATION ON SEED PRODUCTIVITY AND ECONOMIC VALUES OF SWEET PEPPER
}

\author{
Luba Pylypenko $\bowtie$ \\ luba.pilipencko@gmail.com \\ Roman Krutko \\ Oksana Shabetya \\ The Plant Production Institute named after V. Ya. Yuriev \\ of the National Academy of Agrarian Sciences of Ukraine \\ 142 Moskovskyi ave., Kharkiv, Ukraine, 61060 \\ ${ }^{1}$ Institute of Vegetable and Melon Growing \\ of the National Academy of Agrarian Sciences of Ukraine \\ 1 Institutskaya str., p.o. Selektsiyne, Kharkiv rg., Ukraine, 62478
}

$\triangle$ Corresponding author

\begin{abstract}
The use of intra-varietal crossing is an important element to increase seed yield and improve a variety. The aim of the research was to identify the influence of different options of intra-varietal pollination of sweet pepper on seed productivity and other quantitative traits.

It has been established, that re-pollination of sweet pepper within the variety in relation to self-pollination causes a reduction in the offspring of the period before fruit ripening by 3-7 days. For all options of pollination, there was also a significant increase in plant height by $7-8 \mathrm{~cm}$, fruit weight by $7-16 \mathrm{~g}$, the number of fruits on a plant by $2-6$ units.

Different methods of re-pollination of plants significantly affected fruit productivity, increasing it by $62-106 \%$, increased seed yield from one fruit by $28 \%$. Seed productivity of sweet pepper plants increased by $78-163 \%$ when re-pollination was used.

Options of using the pollen of different flowers (from 2-5 other plants) showed the greatest effect. This technique is one way to increase the yield of sweet pepper seeds.
\end{abstract}

Keywords: intra-varietal pollination, sweet pepper, seed productivity, pollen mixture, re-pollination of plants.

DOI: 10.21303/2504-5695.2021.002109

\section{Introduction}

Sweet pepper (Capsicum annuum L.) is the main vegetable crop, which has not only high taste, dietary and nutrients, but also a high content of vitamins, including vitamin $\mathrm{C}$ (up to $400 \mathrm{mg} / 100 \mathrm{~g}$ ) [1]. Also, fruits of this culture contain other valuable vitamins - $\beta$-carotene (provitamin $A$ ), rutin (vitamin $P$ ), thiamine $\left(B_{1}\right)$, riboflavin $\left(B_{2}\right)$, nicotinic and folic acid, proteins and mineral salts [2] . At the level of high taste, the fruits are also a valuable raw material for the canning industry.

The high demand for this crop requires the development of methods that not only increase plant productivity, but also improve the quality of seed material.

The main task of seed production is to ensure the production of high quality seeds and preservation of its economically valuable features. To do this, it is necessary to grow seeds on a high agricultural background in compliance with all technological recommendations: spatial isolation, continuous selection from generation to generation to consolidate and strengthen the main features of the variety [3].

It is known, that each variety retains its hereditary qualities well in several generations under different growing conditions. But without proper primary seed production, the economic 
and biological indicators of a variety gradually deteriorate, resistance to adverse abiotic and biotic factors decreases. Constant cultivation and selection in the same environmental conditions leads to a decrease in the viability and productivity of a variety [4].

In this regard, it is advisable to introduce varietal renewal, which not only ensures high seed quality, but also preserves all the valuable economic and biological characteristics of a variety $[1,5]$. An important element for increasing seed yield is the use of intra-varietal crossing and additional pollination [6-8]. In this case, the formation of seeds is greatly influenced by the quality of pollination. If the pollen comes little on the pistil receptacle, then only part of the seed buds are fertilized, the pericarp grows unevenly, distorted fruits are formed, the seeds of them may be characterized by mutational changes [9].

A number of scientists who have conducted research on additional pollination of plants argue that in greenhouses, sweet pepper flowers get better quality fruits at pollination by bees than fruits that develop as a result of self-pollination [10-12]. It was noted, that the correlation between the number of seeds and fruit size indicated that fertilization of more eggs contributed to fruit growth. It was found, that the weight and size of a fruit, the number of seeds correlated with the amount of pollen, applied to the stigma [12]. Auxin, which is produced in the pollen, endosperm and embryo of a developing seed, is involved in the regulation of development, as it creates an initial stimulus for fruit growth [13].

Scientists have found that intra-varietal crossing provides the best results for re-pollination of plants, grown from seeds of different years of harvest or from different soil and climatic zones. At the same time the quality of seeds improves due to re-pollination of biologically diverse plants. Thus, the carrot yield increased by 10-21\% due to pollination of plants from spring and winter crops [14]. The pepper yield increased by $2.3-25.7 \%$ compared to the control, and fruit weight by $2-11 \%$ [15]. The tomato yield increased by $15-20 \%$ due to re-pollination of lines within one variety [16]. Positive results from intra-varietal crosses were obtained by other researchers with cultures:

- tomato [17];

- chamomile [18];

- coconut palm [19];

- blueberries [20].

Similar studies that would increase seed productivity on sweet peppers have not been conducted, so the question is quite relevant.

The aim of the study is to identify the impact of different options of intra-varietal pollination on seed productivity and other economically valuable traits.

\section{Materials and Methods}

The work was performed during 2019-2020 at the Institute of Vegetable and Melon Growing of NAAS, located in the Left Bank Forest-Steppe of Ukraine. The research material was sweet pepper varieties "Lada". The scheme of the experiment contained 5 options:

1. Self-pollination (control).

2. Re-pollination within a plant.

3. Pollination with the pollen of the $1^{\text {st }}$ flower from another plant.

4. Pollination with a mixture of the pollen from 2 flowers from other plants.

5. Pollination with a mixture of the pollen from 5 flowers from other plants.

For pollination there were used 5 plants for each option. Castration and pollination were performed in the morning from 6 to 10 o'clock. Pollinated flowers were labeled and insulated with cotton wool. To increase the supply of nutrients to pollinated flowers, all unpollinated flowers were removed.

Plants from the obtained seeds were grown by the seedling method. Seedlings aged 60 days were planted in the second decade of May, planting scheme $(70+40) \times 40 \mathrm{~cm}$. Plots were laid in 4-fold repetition of 10 accounting plants. Agrotechnical measures included weeding, fertilizing, irrigation, pest and disease control. In the process of plant growth and development, regular observations and biometric measurements were performed. According to phenological indicators there 
were noted: date of sowing, germination, 1st true leaf, budding, flowering, technical and physiological ripeness. According to biometric indicators - height and diameter of plants, length and diameter of fruits, weight of the $1^{\text {st }}$ fruit, as well as the number of fruits on the plant. The fruit and seed productivity was also recorded. The analysis of experimental data was performed using the ANOVA method. Differences between values in different options of the experiment were determined using the Tukey test [21], where the differences were considered significant at $P<0.05$ (taking into account the Bonferroni correction [22]).

\section{Results}

It has been established, that with the use of all re-pollination options the vegetation period of sweet pepper plants is reduced in comparison with the control by 3-7 days. The greatest effect in this regard was achieved when using a mixture of different pollen (for pollination of mother plants with a mixture of the pollen from two or five flowers of other plants) (Table 1). This result is formed by accelerating the onset of all major phases of plant development, starting from the formation of the first true leaf (2-5 days).

Table 1

The influence of intra-varietal pollination on the passage of interphase periods by sweet pepper plants (average for 2019-2020)

\begin{tabular}{ccccccc}
\hline & \multicolumn{7}{c}{ Number of days before: } \\
\cline { 2 - 7 } Options & $\begin{array}{c}\mathbf{1}^{\text {st }} \text { true } \\
\text { leaf }\end{array}$ & budding & $\begin{array}{c}\text { flower- } \\
\text { ing }\end{array}$ & Fruit formation & $\begin{array}{c}\text { Technical } \\
\text { ripeness }\end{array}$ & $\begin{array}{c}\text { Physiological } \\
\text { ripeness }\end{array}$ \\
\hline $\begin{array}{c}\text { Self-pollination (control) } \\
\text { Re-pollination within one plant }\end{array}$ & $12 \pm 0.4$ & $73 \pm 1.0$ & $96 \pm 1.1$ & $104 \pm 1.0$ & $124 \pm 1.2$ & $151 \pm 1.0$ \\
$\begin{array}{c}\text { Pollination by the pollen of the 1st } \\
\text { flower of another plant }\end{array}$ & $11 \pm 0.7$ & $70 \pm 1.0$ & $94 \pm 1.5$ & $103 \pm 1.1$ & $119 \pm 1.2$ & $147 \pm .1 .0$ \\
$\begin{array}{c}\text { Pollination with a mixture of the pol- } \\
\text { len from 2 flowers from other plants }\end{array}$ & $10 \pm 0.7$ & $70 \pm 1.0$ & $93 \pm 1.3$ & $101 \pm 1.0$ & $119 \pm 1.1$ & $144 \pm 1.1$ \\
$\begin{array}{c}\text { Pollination with a mixture of the pol- } \\
\text { len from 5 flowers from other plants }\end{array}$ & $10 \pm 0.6$ & $66 \pm 1.1$ & $91 \pm 1.4$ & $102 \pm 1.1$ & $119 \pm 1.3$ & $144 \pm 1.2$
\end{tabular}

Numerical data in the table are presented as $x \pm S D(n=10)$

It has been established, that re-pollination in relation to self-pollination causes an increase in the values of a number of biometric parameters of sweet pepper plants (Table 2). For all options of pollination there is a significant increase in plant height by $7-8 \mathrm{~cm}$. The width of the plant and the index of the fruit do not vary significantly from different methods of pollination.

Table 2

The influence of intra-varietal pollination on biometric indicators of sweet pepper plants (average for 2019-2020)

\begin{tabular}{|c|c|c|c|c|c|}
\hline Options & $\begin{array}{c}\text { Plant } \\
\text { height, } \mathrm{cm}\end{array}$ & $\begin{array}{c}\text { Plant } \\
\text { width, cm }\end{array}$ & $\begin{array}{l}\text { Fruit } \\
\text { index }\end{array}$ & $\begin{array}{c}\text { Fruit } \\
\text { weight, } g\end{array}$ & $\begin{array}{c}\text { Number of fruits } \\
\text { on a plant, un }\end{array}$ \\
\hline Self-pollination (control) & $54 \pm 1.7$ & $51 \pm 2.8$ & $1.4 \pm 0.03$ & $57 \pm 2.3$ & $6 \pm 0.3$ \\
\hline Re-pollination within one plant & $61 \pm 2.7$ & $51 \pm 2.2$ & $1.3 \pm 0.02$ & $71 \pm 2.0$ & $8 \pm 0.3$ \\
\hline Pollination by the pollen of the $1^{\text {st }}$ flower of another plant & $61 \pm 2.3$ & $50 \pm 3.0$ & $1.3 \pm 0.02$ & $73 \pm 2.2$ & $8 \pm 0.3$ \\
\hline $\begin{array}{l}\text { Pollination with a mixture of the pollen from } 2 \text { flowers } \\
\text { from other plants }\end{array}$ & $61 \pm 2.3$ & $52 \pm 2.3$ & $1.3 \pm 0.02$ & $66 \pm 2.5$ & $11 \pm 0.5$ \\
\hline $\begin{array}{l}\text { Pollination with a mixture of the pollen from } 5 \text { flowers } \\
\text { from other plants }\end{array}$ & $62 \pm 2.2$ & $53 \pm 2.3$ & $1.3 \pm 0.02$ & $64 \pm 2.5$ & $12 \pm 0.8$ \\
\hline
\end{tabular}

Numerical data in the table are presented as $x \pm S D(n=10)$

The pollination methods influenced such elements of the sweet pepper yield formation as the weight of one fruit and the number of fruits per plant. It was noted, that with different methods of pol- 
lination the fruit weight increased by $7-16 \mathrm{~g}$ relative to the control and was the largest in the options for pollination within a plant $(71 \mathrm{~g})$ and pollination of the 1 st flower from another plant $(73 \mathrm{~g})$. The maximum increase in the number of fruits on a plant ensures the use of the pollen from several plants (from two to five), at that a plant produces 11-12 fruits, while at self-pollination -6 fruits.

It was noted, that different methods of plant pollination significantly affected the seed productivity of sweet pepper mainly due to the parameter of fruit productivity (fruit yield from one plant) and partly due to the increased seed yield from one fruit (Table 3). The fruit productivity was highest in the case of pollination with a mixture of the pollen from five other plants $(682 \mathrm{~g})$ and pollination with a mixture of the pollen from two other plants "(632 g), which exceeded self-pollination by $92-106 \%$.

Table 3

The influence of intra-varietal pollination on seed productivity of sweet pepper plants (average for 2019-2020)

\begin{tabular}{ccccccc}
\hline & Fruit productivity, g/plant & Seed yield from the 1st fruit & Seed productivity, g/plant \\
\cline { 2 - 7 } Options & $\mathbf{g}$ & $\begin{array}{c}\text { Comparing to } \\
\text { control, \% }\end{array}$ & $\mathbf{g}$ & $\begin{array}{c}\text { Comparing to } \\
\text { control, \% }\end{array}$ & $\begin{array}{c}\text { g } \\
\text { Comparing to } \\
\text { control, \% }\end{array}$ \\
\hline $\begin{array}{c}\text { Self-pollination (control) } \\
\text { Re-pollination within one plant }\end{array}$ & $330 \pm 14.2$ & 100 & $0.7 \pm 0.05$ & 100 & $3.8 \pm 0.08$ & 100 \\
$\begin{array}{c}\text { Pollination by the pollen of the 1 } \\
\quad \text { ft } \\
\text { flower of another plant }\end{array}$ & $542 \pm 30.7$ & 164 & $0.9 \pm 0.01$ & 128 & $6.8 \pm 0.05$ & 178 \\
$\begin{array}{c}\text { Pollination with a mixture of the pol- } \\
\text { len from 2 flowers from other plants }\end{array}$ & $632 \pm 38.5$ & 192 & $0.9 \pm 0.04$ & 128 & $9.0 \pm 0.01$ & 236 \\
$\begin{array}{c}\text { Pollination with a mixture of the pol- } \\
\text { len from 5 flowers from other plants }\end{array}$ & $682 \pm 35.8$ & 206 & $0.9 \pm 0.01$ & 128 & $10.0 \pm 0.07$ & 263
\end{tabular}

Numerical data in the table are presented as $x \pm S D(n=10)$

Intra-varietal pollination leads to an increase in seed yield from one fruit by $28 \%$, but between different pollination methods, this figure did not change.

The introduction of intra-varietal pollination causes an increase in seed productivity of sweet pepper plants by $78-163 \%$. The maximum increase in seed productivity is ensured by the use of pollination of a mixture of the pollen from five plants, which leads to an increase in seed productivity by 2.5 times compared to the option of self-pollination. This phenomenon is due to the faster germination of the pollen on the stigma of another flower. It can also be noted, that the more pollen we use from more plants, the higher the productivity of fruits and seeds.

Thus, the analysis of the obtained results shows that there is a difference between self-pollination (control) and re-pollination of a mixture of the pollen from other plants of the same variety. The reason is that during self-pollination for a more or less long time the hereditary basis of the variety becomes poorer, homozygous, then the variety weakens and ceases to give high yields. And when re-pollinated from other plants, the offspring with the enriched hereditary basis comes, which has the higher viability. Therefore, the studied options can be used to improve and update the variety.

\section{Conclusions}

Thus, the introduction of intra-varietal pollination reduces the period before fruit ripening, improves the biometric parameters of plants and increases fruit productivity by $62-106 \%$ and seed productivity of plants by $78-163 \%$. Options using the pollen of different flowers (from 2-5 other plants) showed the greatest effect. This technique is one way to increase the yield of sweet pepper seeds.

\section{References}

[1] Filov, A. Y. (1956). Vegetables and eggplants. Leninhrad: Selkhozizd, 368.

[2] Bolotskykh, A. S. (2001). Vegetables of Ukraine. Kharkiv: Orbita, 1088.

[3] Ludilov, V. A. (2000). Seed growing of vegetables and melons Crops. Moscow, 56-72. 
[4] Vitanov, O. D. (Ed.) (2018). Seed production of vegetable plants. Vinnytsia: TOV «TVORY», 254. Available at: http:// dspace.knau.kharkov.ua/jspui/handle/123456789/2080?mode=full

[5] Berova, M., Karanatsidis, G. (2008). Physiological response and yield of pepper plants (Capsicum annum L.) to organic fertilization. Journal of Central European Agriculture, 9 (4), 715-722.

[6] Bo, M. L., Carrizo García, C. (2015). Pollen phenotyping and performance in rocoto chili (Capsicum pubescensRuiz et Pav., Solanaceae). Grana, 54 (1), 37-44. doi: https://doi.org/10.1080/00173134.2014.985606

[7] De Ruijter, A., van den Eijnde, J., van der Steen, J. (1991). Pollination of sweet pepper (Capsicum Annuum L.) In greenhouses by honeybees. Acta Horticulturae, 288, 270-274. doi: https://doi.org/10.17660/actahortic.1991.288.41

[8] Berger, F., Hamamura, Y., Ingouff, M., Higashiyama, T. (2008). Double fertilization - caught in the act. Trends in Plant Science, 13 (8), 437-443. doi: https://doi.org/10.1016/j.tplants.2008.05.011

[9] Kravchenko, V. A., Prylipka, O. V. (2002). Selection and seed production of vegetable crops in the closed ground. Kyiv: Ahrarna nauka, 280.

[10] Dag, A., Kamer, Y. (2001). Comparison between the effectiveness of honeybee (Apis mellifera) and bumblebee (Bombus terrestris) as pollinators of greenhouse sweet pepper (Capsicum annuum). American Bee Journal, 141 (6), 447-448.

[11] Ercan, N., Onus, A. N. (2003). The effects of bumblebees (Bombus terrestris L.) on fruit quality and yield of pepper (Capsicum annuum L.) grown in an unheated greenhouse. Israel Journal of Plant Sciences, 51 (4), 275-283. doi: https://doi.org/10.1560/ n7fl-2bbu-x619-vlfg

[12] Roldán Serrano, A., Guerra-Sanz, J. M. (2006). Quality fruit improvement in sweet pepper culture by bumblebee pollination. Scientia Horticulturae, 110 (2), 160-166. doi: https://doi.org/10.1016/j.scienta.2006.06.024

[13] Taiz, L., Zeiger, E. (2010). Gibberellins: Regulators of Plant Height. Plant Physiology, 690.

[14] Bunyn, M. S. (2002). New vegetable crops in Russia. Moscow: FHNU «Rosynformahrotekh», 407.

[15] Kozlovskaya, E. A., Pyshnaya, O. N., Mamedov, M. I., Djos, E. A., Mitrofanova, O. A. (2018). Intra-varietal crossing as method to improve adaptation characteristics in initial breeding accessions. Vegetable Crops of Russia, 5, 18-20. doi: https://doi.org/ 10.18619/2072-9146-2017-5-18-20

[16] Alpatev, A. V. (1981). Genetic-physiological method in the selection of vegetable nightshade crops (tomatoes and peppers). VASKHNIL reports, 7, 3-5.

[17] Kylchevskyi, A. V., Khotyleva, L. V. (1997). Ecological plant breeding. Mynsk: Tekhnolohyia, 372.

[18] Totskaya, S. A., Grjaznov, M. U., Hazieva, F. M. (2015). Selection work with camomile. International research journal, 4 (35), 123-125. Available at: https://research-journal.org/agriculture/selekcionnaya-rabota-s-romashkoj-aptechnoj/

[19] Azevedo, A. O. N., Azevedo, C. D. de O., Santos, P. H. A. D., Ramos, H. C. C., Boechat, M. S. B., Arêdes, F. A. S. et. al. (2018). Selection of legitimate dwarf coconut hybrid seedlings using DNA fingerprinting. Crop Breeding and Applied Biotechnology, 18 (4), 409-416. doi: https://doi.org/10.1590/1984-70332018v18n4a60

[20] Lang, G. A., Danka, R. G. (1991). Honey-bee-mediated Cross- versus Self-pollination of 'Sharpblue’ Blueberry Increases Fruit Size and Hastens Ripening. Journal of the American Society for Horticultural Science, 116 (5), 770-773. doi: https://oi.org/ 10.21273/jashs.116.5.770

[21] Tukey, J. W. (1949). Comparing Individual Means in the Analysis of Variance. Biometrics, 5 (2), 99. doi: https://doi.org/ $10.2307 / 3001913$

[22] Armstrong, R. A. (2014). When to use the Bonferroni correction. Ophthalmic and Physiological Optics, 34 (5), 502-508. doi: https://doi.org/10.1111/opo.12131

How to cite: Pylypenko, L., Krutko, R., Shabetya, O. (2021). Influence of different options of intra-varietal pollination on seed productivity and economic values of sweet pepper. EUREKA: Life Sciences, 6, 3-7. doi: https://doi.org/10.21303/2504-5695.2021.002109 